\title{
Halococcus salifodinae sp. nov., an Archaeal Isolate from an Austrian Salt Mine
}

\author{
EWALD B. M. DENNER, ${ }^{1}$ TERRY J. MCGENITY ${ }^{2}$ HANS-JÜRGEN BUSSE, ${ }^{1}$ WILLIAM D. GRANT, ${ }^{2}$ \\ GERHARD WANNER, ${ }^{3}$ AND HELGA STAN-LOTTER ${ }^{1 *}$ \\ Institute of Microbiology and Genetics, University of Vienna, A-1030 Vienna, Austria ; Department of \\ Microbiology, University of Leicester, Leicester, England LE1 $9 \mathrm{HN}^{2}$; and Botanisches Institut \\ der Universität München, D-80638 Munich, Germany ${ }^{3}$
}

\begin{abstract}
A novel extremely halophilic archaeon (archaebacterium) was isolated from rock salt obtained from an Austrian salt mine. The deposition of the salt is thought to have occurred during the Permian period $(225 \times$ $10^{6}$ to $280 \times 10^{6}$ years ago). This organism grew over a pH range of 6.8 to 9.5 . Electron microscopy revealed cocci in tetrads or larger clusters. The partial 16S rRNA sequences, polar lipid composition, and menaquinone content suggested that this organism was related to members of the genus Halococcus, while the whole-cell protein patterns, the presence of several unknown lipids, and the presence of pink pigmentation indicated that it was different from previously described coccoid halophiles. We propose that this isolate should be recognized as a new species and should be named Halococcus salifodinae. The type strain is BIp (= ATCC 51437 = DSM 8989). A chemotaxonomically similar microorganism was isolated from a British salt mine.
\end{abstract}

Viable halophilic microorganisms have been isolated recently from various ancient salt deposits in England which originated in the Triassic period $\left(195 \times 10^{6}\right.$ to $225 \times 10^{6}$ years ago) or the Permian period $\left(225 \times 10^{6}\right.$ to $280 \times 10^{6}$ years ago $)$ (18). We have also been able to cultivate halophilic bacteria from rock salt which was obtained from the Austrian salt mine near Bad Ischl; this salt is believed to have been deposited during the Permian period (30). A preliminary biochemical description of some of the isolates obtained from the British salt deposits as well as the Austrian salt mines has been published previously (24). In this paper we present a detailed characterization of one of the Austrian halophilic coccoid isolates (strain $\mathrm{Blp}^{\mathrm{T}}[\mathrm{T}=$ type strain]) which could grow over a wide $\mathrm{pH}$ range, and we propose a new species, Halococcus salifodinae.

\section{MATERIALS AND METHODS}

Culture conditions and bacterial strains. The methods used to isolate bacteria from dry rock salt have been described previously (24). The $\mathrm{pH}$ of the growth medium (M2 medium [27]) was 7.4, unless indicated otherwise. When a $\mathrm{pH}$ of $>8.5$ was desired, the medium of Tindall et al. (26) was used, and the $\mathrm{pH}$ was adjusted accordingly. Growth in liquid cultures was monitored spectrophotometrically at $600 \mathrm{~nm}$ with a Novaspec II instrument (Pharmacia) or at $660 \mathrm{~nm}$ (red filter of a Klett-Summerson colorimeter). Utilization of carbohydrates was tested in minimal medium M2A, which contained $50 \mathrm{mM}$ Tris- $\mathrm{HCl}, 4 \mathrm{M} \mathrm{NaCl}, 0.1 \%$ yeast extract, $1 \mathrm{mM} \mathrm{NH}_{4} \mathrm{Cl}$, $27 \mathrm{mM} \mathrm{KCl}, 100 \mathrm{mM} \mathrm{MgCl}_{2}, 1.4 \mathrm{mM} \mathrm{CaCl}, 0.1 \%$ trace elements solution SL-6 (12), $1 \%$ carbohydrate, and $0.002 \%$ phenol red as a $\mathrm{pH}$ indicator. Growth on carbon sources was determined by monitoring turbidity and was compared with growth of a culture in minimal medium that contained no added carbohydrates. The range of salt concentrations which permitted growth was determined by spreading $100-\mu 1$

${ }^{*}$ Corresponding author. Mailing address: Institut für Genetik und Allgemeine Biologie, Universität Salzburg, Hellbrunnerstr. 34, A-5020 Salzburg, Austria. Fax: 43-662-8044-5795. portions of a growing culture on agar plates containing M2 medium supplemented with final $\mathrm{NaCl}$ concentrations of 0 , $0.5,1.0,2.5,5,7.5,10,12.5,15,17.5,20,22.5,25$, and $30 \%$. Cultures of strain Blp ${ }^{\mathrm{T}}$ on agar plates were incubated for 10 to 20 days.

The following archaeal strains were obtained from the Deutsche Sammlung von Mikroorganismen und Zellkulturen: Halobacterium salinarium DSM 668, Halococcus morrhuae DSM $1307^{\mathrm{T}}$ and DSM 1309, Halococcus saccharolyticus DSM $5350^{\mathrm{T}}$, Natronococcus occultus DSM $3396^{\mathrm{T}}$, Natronobacterium magadii DSM $3394^{\mathrm{T}}$, Natronobacterium gregoryi DSM $3393^{\mathrm{T}}$, and Natronobacterium pharaonis DSM 3395. The strains used to determine the data in Table 1 and for Fig. 5 were obtained from the National Collection of Industrial and Marine Bacteria, Ltd., Aberdeen, Scotland, or from sources described in reference 13. Halobacterium saccharovorum M6 (= ATCC 29252), Halobacterium halobium R1, Haloferax denitrificans ATCC 35960, and Haloarcula vallismortis were obtained from L. I. Hochstein, NASA Ames Research Center; Haloarcula californiae ATCC 33799 and Haloarcula hispanica were gifts from R. H. Vreeland, West Chester University; and Haloarcula japonica TR-1 was a gift from K. Horikoshi, The Riken Institute.

Biochemical tests. Catalase activity was determined by placing 1 drop of a $3 \%(\mathrm{vol} / \mathrm{vol}) \mathrm{H}_{2} \mathrm{O}_{2}$ solution on a lawn of bacteria; the formation of gas bubbles indicated a positive reaction. Oxidase activity was detected by spotting a loopful of a bacterial culture on a paper strip containing $N, N$-dimethyl1,4-phenylenediammonium chloride and $\alpha$-naphthol; a blue color revealed the presence of the enzyme. Nitrate reduction was determined as described previously (22). Gelatin liquefaction was assayed in tubes containing M2 broth supplemented with $12 \%$ gelatin as described by Tomlinson and Hochstein (27) following incubation at $37^{\circ} \mathrm{C}$ for 4 weeks.

Analysis of lipids and menaquinones. The preparation of polar lipid extracts and analysis by two-dimensional thin-layer chromatography have been described by Ross et al. (21). Menaquinones were extracted with acetone from lyophilized cells and were purified by thin-layer chromatography (10). Menaquinones were separated on a reverse-phase column 


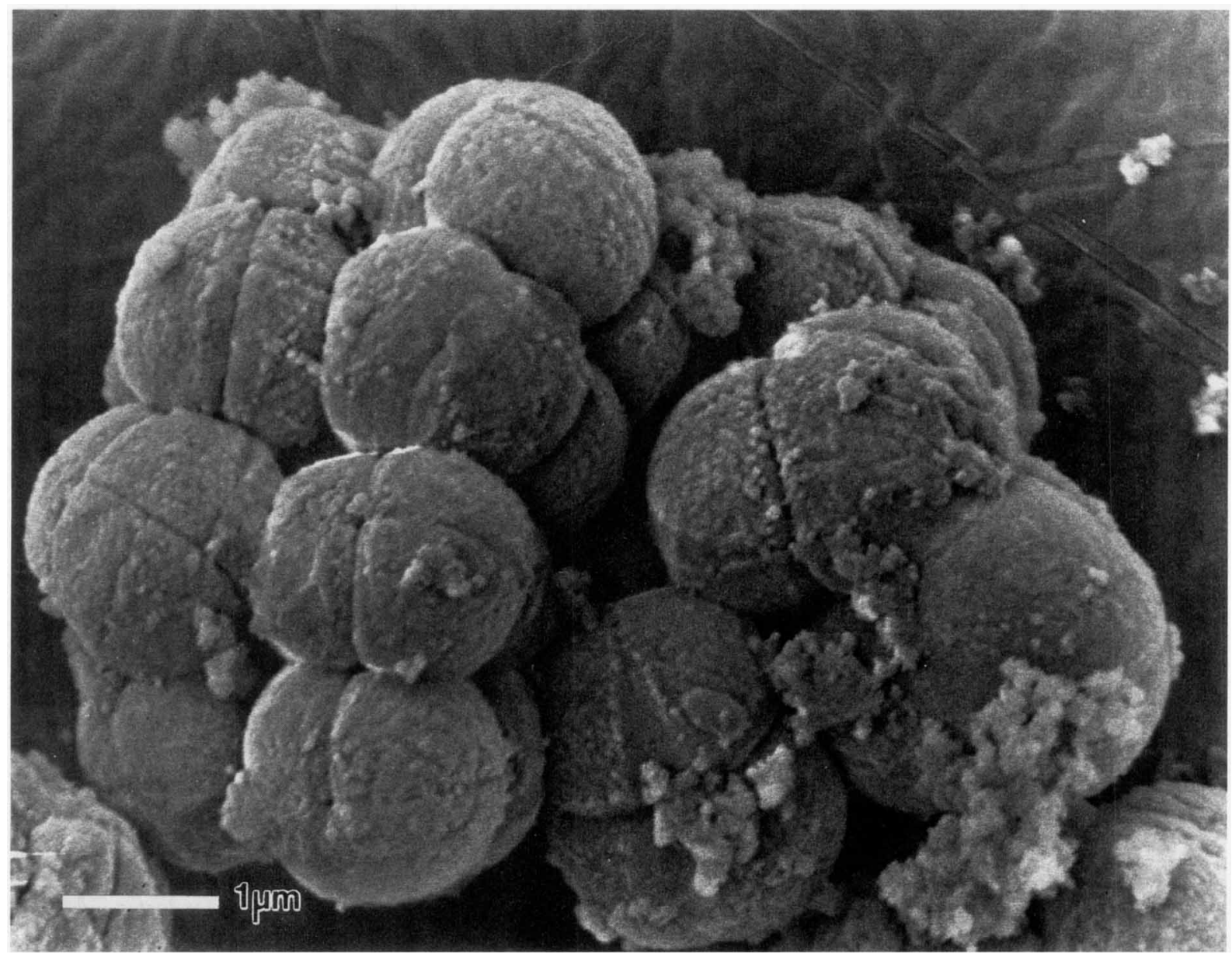

FIG. 1. High-resolution field emission scanning electron micrograph of $\mathrm{Blp}^{\mathrm{T}}$ grown in liquid culture (M2 medium, $\mathrm{pH} 7.4$ ) to the end of the exponential phase. The accelerating voltage was $3 \mathrm{kV}$.

$\left(\mathrm{C}_{18}\right)$ by high-performance liquid chromatography (HPLC) (Waters Instruments), and separation was monitored with a UV detector at $269 \mathrm{~nm}$. A mixture of methanol and 2-chlorobutane $(9: 1)$ was used as the eluent; the flow rate was $1 \mathrm{ml} / \mathrm{min}$. Quinones were identified by comparison with the quinones extracted from Halobacterium saccharovorum M6.

DNA base composition. Cells were harvested in the early stationary phase of growth, and $\mathrm{G}+\mathrm{C}$ contents were determined by the Identification Service of the Deutsche Sammlung von Mikroorganismen und Zellkulturen, Braunschweig, Germany. DNA was isolated by the procedure of Visuvanathan et al. (28) and was analyzed by HPLC. Nonmethylated lambda virus DNA was used for calibration (15).

Sequencing of 16S rRNA and analysis. DNA extraction, amplification of the 16S rRNA gene by the PCR, and sequence analyses were performed as described by McGenity and Grant (13), except that only one of the primers (517 R) was used. A total of 212 bases were sequenced from the 16S rRNA gene of $\mathrm{Blp}^{\mathrm{T}}$ and a similar isolate obtained from a British salt mine (strain $\mathrm{Br} 3$ ) (18).

Electron microscopy. Cells were washed three times with a buffer containing $2 \mathrm{mM} \mathrm{MgSO}_{4}$ and $75 \mathrm{mM}$ sodium cacodylate ( $\mathrm{pH} 7.2)$ and then were fixed with $2 \%$ glutaraldehyde in the same buffer for $1 \mathrm{~h}$ at room temperature and washed again. The cells were prepared for scanning or transmission electron microscopy as described by Witte et al. (29). Scanning electron microscopy and transmission electron microscopy were performed with a Hitachi model S-4100 field emission scanning electron microscope and a Siemens Elmiscop 101 transmission electron microscope, respectively.

Other methods. Unstained cells were observed with a Leitz Diaplan microscope by using phase-contrast techniques. Gram staining of cells was carried out as described by Dussault (2). Assays to determine antibiotic susceptibility, lysis of halobacterial cells in water, and sodium dodecyl sulfate-polyacrylamide gel electrophoresis (SDS-PAGE) or isoelectric focusing of whole-cell proteins were performed as described previously $(23,24)$. In addition to the antibiotic aphidicolin used previously, $40 \mu \mathrm{g}$ of each of the following antibiotics per disc was used in this study: ampicillin, anisomycin, bacitracin, chloramphenicol, nalidixic acid, novobiocin, streptomycin, and tetracycline. Lysis by bile acids was assayed by monitoring the turbidity of cells suspended in a solution which consisted of $1 \%$ Bacto-Peptone (catalog no. 0118-01; Difco) in $20 \% \mathrm{NaCl}$, as described by Kamekura et al. (8). In addition, cells suspended in this solution were observed by phase-contrast microscopy for a total of $24 \mathrm{~h}$.

Nucleotide sequence accession numbers. The full 16S rRNA sequence of Natronococcus occultus as determined by $\mathrm{Mc}$ Genity and Grant (13) was deposited in the EMBL Data Library under accession number Z28378; partial 16S rRNA 


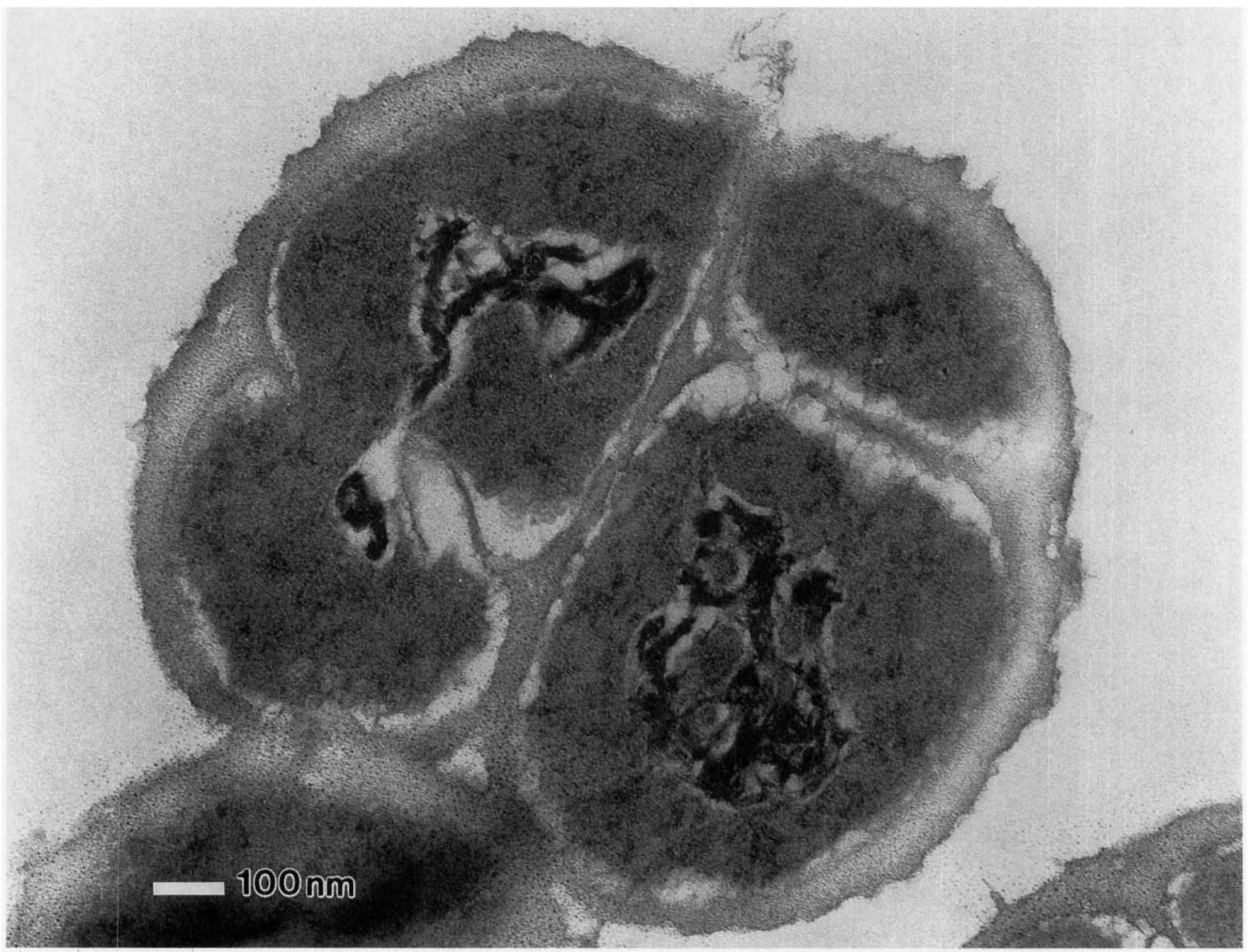

FIG. 2. Electron micrograph of an ultrathin section of $\mathrm{Blp}^{\mathrm{T}}$ grown as described in the legend to Fig. 1 .

sequences of strains $\mathrm{Br} 3$ and $\mathrm{Blp}^{\mathrm{T}}$ (this study) were deposited under accession numbers Z28379 and Z28387, respectively.

\section{RESULTS AND DISCUSSION}

Cell and colony morphology. Isolate $\mathrm{Blp}^{\mathrm{T}}$ cells were cocci about 0.8 to $1.2 \mu \mathrm{m}$ in diameter (Fig. 1 and 2). The cells were uniformly gram negative, whether they were from 3-, 5-, or 14-day-old cultures. Cells grown in liquid medium were nonmotile and occurred in tetrads, in sarcina-like packets or (in older cultures) in large clusters (Fig. 1). Thin sections revealed a thick cell envelope (Fig. 2) with an irregular outer layer. Some of the outermost material appeared to be detachable (Fig. 1) and may have represented an extracellular slime which held the cells together. Colonies on complex medium at $\mathrm{pH} 7.4$ were circular with undulate margins and about 1 to $2 \mathrm{~mm}$ in diameter after 10 days of incubation at $37^{\circ} \mathrm{C}$ and had pink pigmentation; older colonies were brownish. Colonies on medium at $\mathrm{pH} 9.5$ were nonpigmented.

Cultural and biochemical characteristics. Strain $\mathrm{Blp}^{\mathrm{T}}$ grew aerobically with doubling times of 24 to $28 \mathrm{~h}$ at $37^{\circ} \mathrm{C}$ in liquid M2 medium ( $\mathrm{pH} 7.4$ ) with shaking. Catalase, nitrate reductase, and oxidase activities were detected. Gelatin was liquefied. Growth in test tubes containing broth occurred as sediment.

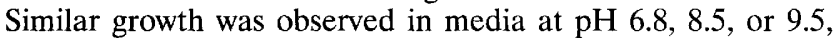
with no apparent $\mathrm{pH}$ optimum in this range. No growth occurred at $\mathrm{pH} 10.5$ or below $\mathrm{pH} 6.0$; growing cells which were suspended in media at those $\mathrm{pH}$ values appeared to lyse slowly. Optimal growth occurred at $\mathrm{NaCl}$ concentrations of 20 to $25 \%$; no growth was observed at $\mathrm{NaCl}$ concentrations below $15 \%$. Like the cells of other halococci, the cells did not lyse within 1 to $2 \mathrm{~h}$ when they were suspended in distilled water (5). However, after incubation for $24 \mathrm{~h}$, a portion of the cells had lysed, releasing proteins whose compositions were similar to the compositions shown in Fig. 3, lane 1. No lysis occurred when cells were suspended in a $20 \% \mathrm{NaCl}$ solution containing bile acids, as was observed with other halococci (8). The temperature range for growth was between 28 and $50^{\circ} \mathrm{C}$, and the optimum temperature was $40^{\circ} \mathrm{C}$. A minimal medium containing $0.1 \%$ yeast extract supported growth when carbohydrates were present. D-Glucose, D-fructose, D-trehalose, D-raffinose, and glycerol were utilized with slight acidification of the medium, whereas utilization of D-galactose, L-rhamnose, D-xylose, and D-arabinose produced more intense acidification. Erythritol was not utilized.

Growth of $\mathrm{Blp}{ }^{\mathrm{T}}$ was strongly inhibited by the antibiotics anisomycin, aphidicolin, bacitracin, and novobiocin. Moderate susceptibility to chloramphenicol and tetracycline was observed. No inhibition of growth occurred with ampicillin, nalidixic acid, or streptomycin.

Gel electrophoresis of whole-cell proteins. SDS-PAGE of whole-cell protein is a rapid method for distinguishing bacterial species, and the level of discrimination of this method is similar to that of DNA-DNA hybridization (6). Strain $\mathrm{Blp}^{\mathrm{T}}$ had a unique protein profile following SDS-PAGE which did not 


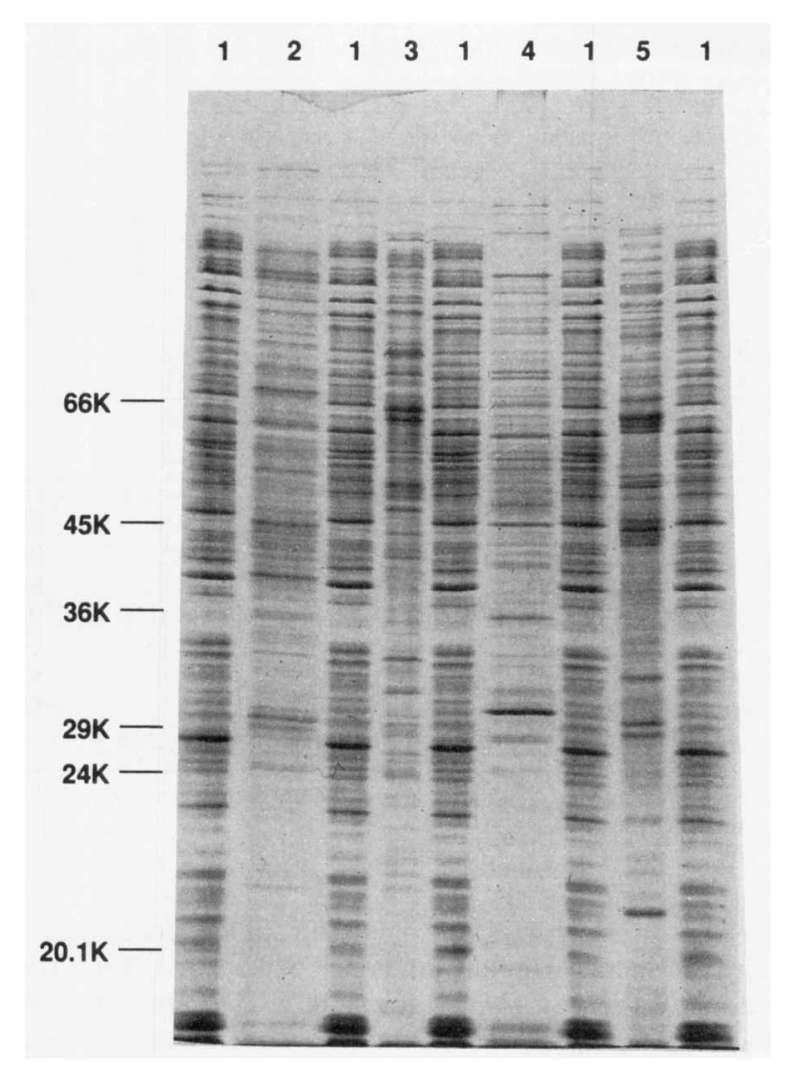

FIG. 3. Whole-cell proteins from various halophilic archaeal strains and Blp following separation by SDS-PAGE. Approximately $20 \mu \mathrm{g}$ of protein was applied per lane following lysis of cells. Proteins were stained with Coomassie blue. Lanes 1, Blp ${ }^{\mathrm{T}}$; lane 2, Halococcus saccharolyticus DSM 5350' ; lane 3, Natronococcus occultus DSM 3396" lane 4, Halococcus morrhuae DSM 1309; lane 5. Haloarcula californiae. The positions of molecular mass markers are indicated on the left.

resemble the profile of any of the halobacterial type strains which were analyzed. In particular, none of the protein patterns of the halophilic coccoidal archaebacterial strains was similar to the Blp ${ }^{\top}$ pattern (Fig. 3). In addition, the whole-cell protein patterns of Haloarcula californiae (Fig. 3), Haloarcula japonica, Haloarcula hispanica, Halobacterium saccharovorum, Halobacterium halobium R1, Halobacterium salinarium, Haloferax denitrificans, Natronobacterium pharaonis, $\mathrm{Na}$ tronobacterium magadii, and Natronobacterium gregoryi were not similar to the strain $\mathrm{Blp}^{T}$ pattern (data not shown). The protein patterns of $\mathrm{Blp}^{\mathrm{T}}$ were identical, whether the strain was grown at $\mathrm{pH} 7.4$ or $\mathrm{pH}$ 9.5. A coccoidal halophilic isolate obtained from a British salt mine, Br3 (18), produced a whole-cell protein pattern similar to that of strain Blp ${ }^{\mathrm{T}}$; there were only minor differences in the relative intensities of some bands (data not shown).

Extremely halophilic bacteria are known to possess acidic bulk proteins (19), whose isoelectric points range between $\mathrm{pH}$ 3.6 and $5.0(23)$. Isoelectric focusing gels of whole-cell proteins of strain Blp ${ }^{T}$ revealed almost exclusively acidic proteins with isoelectric points between 3.8 and 4.5. The overall protein pattern observed in isoelectric focusing gels was different from the patterns of all of the halophilic archaeal type strains described previously (data not shown).

Polar lipids and menaquinones. Two-dimensional thin-layer chromatography of lipids revealed $\mathrm{C}_{20} \mathrm{C}_{20}$ and $\mathrm{C}_{20} \mathrm{C}_{25}$ archae-

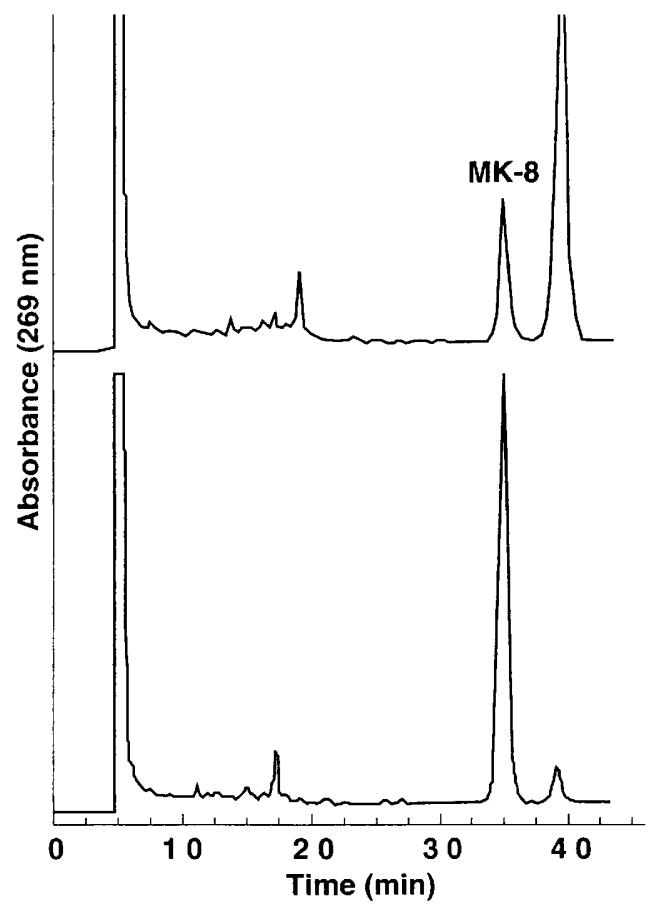

FIG. 4. Separation of menaquinones MK-8 and MK- $8\left(\mathrm{H}_{2}\right)$ from $\mathrm{Blp}^{\mathrm{T}}$ (upper trace) and Halobacterium saccharovorum M6 (lower trace) on a $\mathrm{C}_{18}$ reverse-phase column.

bacterial core lipids. Phosphatidylglycerol and phosphatidylglycerol phosphate were present, but no phosphatidylglycerol sulfate was detected. Five types of glycolipids were found; one of these was sulfated diglycosyldiphytanylglycerol, and the other four were unknown glycolipids. In the HPLC analysis the quinone extract of $\mathrm{Blp}^{\mathrm{T}}$ produced two peaks with the same retention times as peaks detected in an extract of Halobacterium saccharovorum (Fig. 4). Halobacterium saccharovorum M6 is known to possess two types of menaquinones (25); MK-8, a menaquinone with eight isoprenoid units in the side chain, is the main component, while the dihydromenaquinone MK- $8\left(\mathrm{H}_{2}\right)$ has been detected in only minor amounts. Strain $\mathrm{Blp}^{\mathrm{T}}$ also possessed both of these menaquinones, although the major quinone $(77 \%)$ was $\mathrm{MK}-8\left(\mathrm{H}_{2}\right)$, while $\mathrm{MK}-8$ was present in smaller amounts $(23 \%)$. The dominance of menaquinone MK- $8\left(\mathrm{H}_{2}\right)$ in strain $B l p^{T}$ indicated that this strain is related to Halococcus morrhuae, which is also characterized by the presence of major amounts of $\mathrm{MK}-8\left(\mathrm{H}_{2}\right)$ and minor amounts of MK-8 (1).

G $+\mathbf{C}$ content. The DNA base composition of Blp "was $62 \pm$ $1 \mathrm{~mol} \% \mathrm{G}+\mathrm{C}$ (three determinations). This value is within the range found for Halococcus morrhuae (61 to $66 \mathrm{~mol} \%$ ) (11) and similar to the values found for Halococcus saccharolyticus $(59.5 \mathrm{~mol} \%)$ (16) and Natronococcus occultus (65 mol\%) (4).

Phylogeny. Table 1 shows a matrix of similarity values for $\mathrm{Blp}^{T}$ and selected archaeal halophilic reference organisms based on a sequence analysis of 212 bases of the 16S rRNA gene. The sequence of isolate $\mathrm{Br} 3$ in this region was identical to that of $\mathrm{Blp}^{\mathrm{T}}$. On the basis of the phylogenetic tree constructed from this analysis we concluded that $\mathrm{Blp}^{\mathrm{T}}$ represents a distinct lineage within the halophiles and is most similar to 
TABLE 1. Matrix showing relationships between species of halobacteria, based on an analysis of 212 bases of the 16S rRNA gene (positions 227 to 438 in the Halococcus morrhuae ATCC $17082^{\mathrm{T}}$ sequence)

\begin{tabular}{|c|c|c|c|c|c|c|c|c|}
\hline \multirow[b]{2}{*}{ Organism(s) } & \multicolumn{8}{|c|}{ Avg no. of nucleotide substitutions per site or $\%$ similarity $^{a}$} \\
\hline & 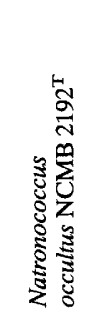 & 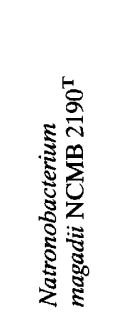 & 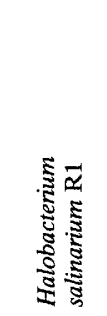 & 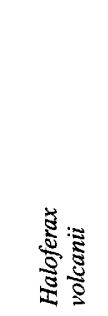 & 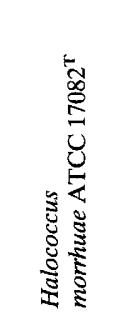 & 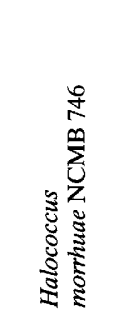 & 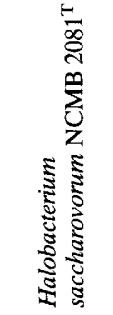 & 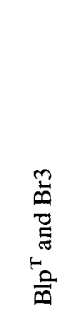 \\
\hline Natronococcus occultus NCMB $2192^{\mathrm{T}}$ & & 94.76 & 92.38 & 92.85 & 91.43 & 89.95 & 89.00 & 89.05 \\
\hline Natronobacterium magadii $\mathrm{NCMB} 2190^{\mathrm{T}}$ & 0.0543 & & 89.62 & 95.75 & 94.81 & 93.36 & 86.19 & 92.42 \\
\hline Halobacterium salinarium $\mathrm{R} 1$ & 0.0803 & 0.1117 & & 91.04 & 88.21 & 88.15 & 90.95 & 89.10 \\
\hline Haloferax volcanii & 0.0751 & 0.0437 & 0.0954 & & 93.87 & 92.89 & 88.10 & 92.42 \\
\hline Halococcus morrhuae ATCC $17082^{\mathrm{T}}$ & 0.0910 & 0.0538 & 0.1283 & 0.0640 & & 98.57 & 87.15 & 95.26 \\
\hline Halococcus morrhuae NCMB 746 & 0.1079 & 0.0695 & 0.1290 & 0.0747 & 0.0144 & & 85.65 & 93.81 \\
\hline Halobacterium saccharovorum NCMB $2081^{\mathrm{T}}$ & 0.1190 & 0.1526 & 0.0964 & 0.1296 & 0.1410 & 0.1593 & & 88.10 \\
\hline $\mathrm{Blp}^{\mathrm{T}}$ and $\mathrm{Br} 3$ & 0.1184 & 0.0799 & 0.1178 & 0.0799 & 0.0490 & 0.0646 & 0.1296 & \\
\hline
\end{tabular}

${ }^{a}$ The values on the lower left are the average numbers of nucleotide substitutions per site $\left(K_{\text {nuc }}\right.$ values) (7), and the values on the upper right are the percentages of similarity. The EMBL Data Library accession numbers for some of the sequences are given in the text.

Halococcus morrhuae ATCC $17082^{\mathrm{T}}$ (Fig. 5). Interestingly, our data indicated that the level of relatedness between Blp ${ }^{T}$ and the alkaliphilic coccus Natronococcus occultus was lower than the level of relatedness between $\mathrm{Blp}^{T}$ and the rod-shaped organism Natronobacterium magadii or the pleomorphic organism Haloferax volcanii (Table 1 and Fig. 5). To date, the

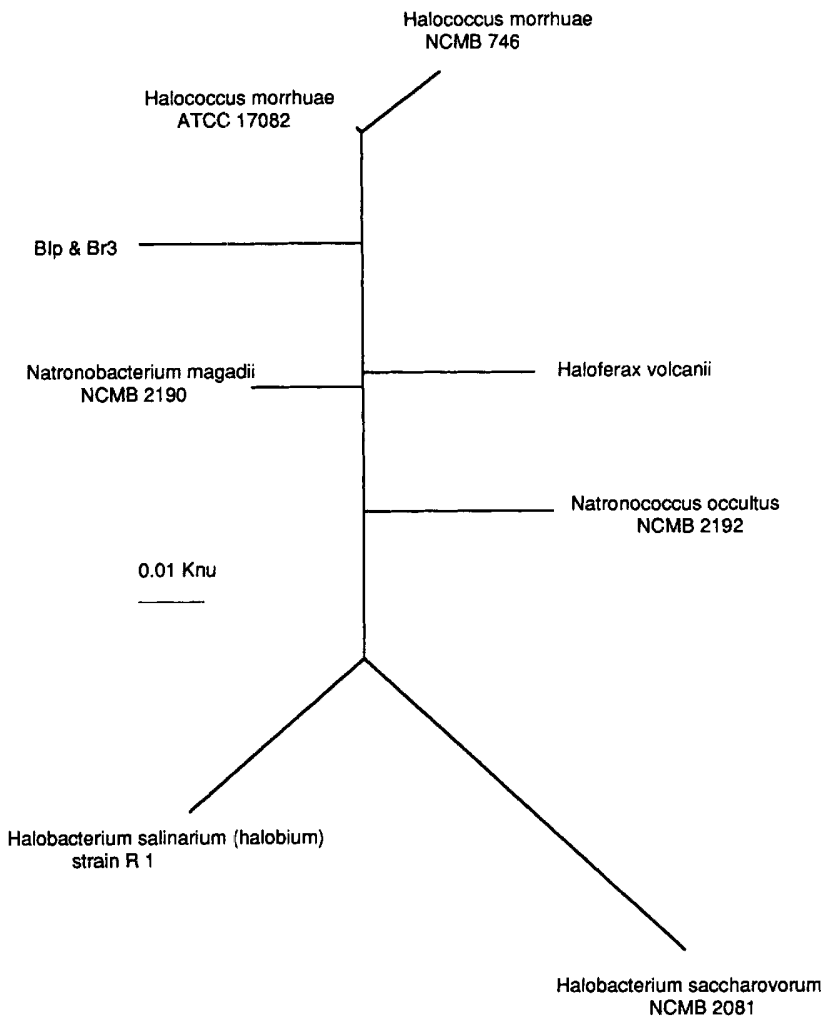

FIG. 5. Unrooted phylogenetic tree of halobacterial species, obtained from the $K_{\text {nuc }}$ values shown in Table 1 by using the least-square algorithm of Fitch and Margoliash (3). following three species of haloneutrophilic cocci and one species of haloalkaliphilic archaeal cocci have been recognized: Halococcus morrhuae, Halococcus saccharolyticus (16), Halococcus turkmenicus (31) and Natronococcus occultus (4). Strain Blp ${ }^{\mathrm{T}}$ could be distinguished from Halococcus morrhuae and Natronococcus occultus as described above (Fig. 3 and Table 1). $\mathrm{Blp}^{\mathrm{T}}$ differed from Halococcus saccharolyticus in pigmentation, the ability to grow at alkaline $\mathrm{pH}$ values, utilization of D-raffinose, L-rhamnose, and $\mathrm{D}$-xylose but not erythritol, susceptibility to novobiocin, and whole-cell protein pattern (Fig. 3). A sequence comparison of the same 212 bases of the $16 \mathrm{~S}$ ribosomal DNA gene indicated that Halococcus turkmenicus is phylogenetically distinct (14).

Conclusions. On the basis of polar lipid content, antibiotic susceptibility, and acidic bulk proteins, strain $\mathrm{Blp}^{\mathrm{T}}$ was identified as a halophilic archaeon (archaebacterium). The morphology, slow growth, and menaquinone content of this organism were similar to Halococcus morrhuae characteristics (11). However, Blp ${ }^{\mathrm{T}}$ differed from Halococcus morrhuae with respect to whole-cell protein pattern, lipid composition, partial $16 \mathrm{~S}$ ribosomal DNA sequence, pigmentation, and $\mathrm{pH}$ range for growth (strain $\mathrm{Blp}^{\mathrm{T}}$ grew at $\mathrm{pH} 6.8$ to 9.5 ). We believe that these data justify our proposal of a new species, Halococcus salifodinae.

Both Blp ${ }^{\mathbf{T}}$ and a similar organism $(\mathrm{Br} 3)$ were isolated from salt mines which contain paleozoic deposits (Alpine basin and Zechstein succession, respectively) (30). When grown in a laboratory, these and other halophilic mine isolates $(18,24)$ were similar in many respects to typical halobacterial inhabitants of evaporitic brines (20). In present-day England and Austria no major saline evaporites are formed, as was the case during the late Permian and early Triassic periods. Taking continental drift into account (30), the two locations were close to the paleoequator during those times, implying that the average temperature was higher and the environment was arid. Disseminative forms such as spores have not been found in any archaebacterium, although halocysts, which might function as resting stages, are produced by some soil-inhabiting species (9). However, several extreme halophiles among the Archaea appear to survive embedding in salt crystals (17) and may be 
capable of dormancy in this state. If the halophilic bacterial mine isolates are the remnants of populations that originally inhabited the paleozoic brines, they might hold great promise as organisms which could enhance our understanding of evolution and bacterial phylogeny. However, direct determination of the age of the salt-embedded microorganisms is not feasible at the present time because of a lack of suitable dating methods. Further experimental approaches will be necessary to establish if a paleozoic origin of the salt mine bacteria can be considered.

Description of Halococcus salifodinae sp. nov. Halococcus salifodinae (sa.li.fo.di'nae. L. adj. salifodinae, of a salt mine, referring to the source of the isolate). Cocci are 0.8 to $1.2 \mu \mathrm{m}$ in diameter and occur in tetrads, sarcina-like packets, and irregular clusters. Gram negative; nonmotile; aerobic. Small colonies ( 1 to $2 \mathrm{~mm}$ in diameter after 1 week of incubation at $37^{\circ} \mathrm{C}$ ) on complex medium at a neutral $\mathrm{pH}$ value are pink and circular, with undulate margins; colonies are nonpigmented at $\mathrm{pH}$ 9.5. The optimum temperature is $40^{\circ} \mathrm{C}$; the $\mathrm{pH}$ range for growth is 6.8 to 9.5 . The optimal $\mathrm{NaCl}$ concentration for growth is 20 to $25 \%$; no growth occurs at $\mathrm{NaCl}$ concentrations below $15 \%$. Oxidase and catalase positive. Grows in minimal medium containing $0.1 \%$ yeast extract and D-galactose, Lrhamnose, D-xylose, D-arabinose, D-glucose, D-fructose, D-trehalose, D-raffinose, or glycerol as carbon sources.

Nitrate is reduced to nitrite. Gelatin is liquefied.

Susceptible to anisomycin, aphidicolin, bacitracin, and novobiocin; slightly susceptible to chloramphenicol and tetracycline; not susceptible to ampicillin, nalidixic acid, and streptomycin.

The $\mathrm{G}+\mathrm{C}$ content of the DNA is $62 \pm 1 \mathrm{~mol} \%$.

The main polar lipids are $\mathrm{C}_{20} \mathrm{C}_{20}$ and $\mathrm{C}_{20} \mathrm{C}_{25}$ derivatives of phosphatidylglycerol and phosphatidylglycerol phosphate. Menaquinones MK- $8\left(\mathrm{H}_{2}\right)$ and MK-8 are present.

Whole-cell proteins are acidic with isoelectric points predominantly between 3.6 and 4.5 .

Natural habitat: unknown.

The type strain is Blp, which has been deposited in the Deutsche Sammlung von Mikroorganismen und Zellkulturen as DSM 8989 and in the American Type Culture Collection as ATCC 51437.

\section{ACKNOWLEDGMENTS}

We acknowledge support from the Bundesministerium für Wissenschaft und Forschung, Austria; the Austrian Fonds zur Förderung der wissenschaftlichen Forschung (grant P9144MOB); NASA Cooperative Agreement NCC2-578 (while H.S. was a Principal Investigator with the SETI Institute); and the Deutsche Forschungsgemeinschaft. This work benefitted from the use of the SEQNET facility.

We thank Silvia Hager for help in obtaining the rock salt samples, Ingrid Kolar and Ilka Dürr for skillful technical assistance, and L. I. Hochstein (NASA Ames Research Center), R. H. Vreeland (West Chester University), and K. Horikoshi (The Riken Institute) for samples of halobacterial strains.

\section{REFERENCES}

1. Collins, M. D., H. N. M. Ross, B. J. Tindall, and W. D. Grant. 1981. Distribution of isoprenoid quinones in halophilic bacteria. J. Appl. Bacteriol. 50:559-565.

2. Dussault, H. P. 1955 . An improved technique for staining red halophilic bacteria. J. Bacteriol. 70:484-485.

3. Fitch, W. M., and E. Margoliash. 1967. Construction of phylogenetic trees based on mutation distance as estimated from cytochrome c sequences is of general applicability. Science 155:279284.

4. Grant, W. D. 1989. Genus VI. Natronococcus, p. 2232-2233. In J. T. Staley, M. P. Bryant, N. Pfennig, and J. G. Holt (ed.),
Bergey's manual of systematic bacteriology, vol. 3. The Williams and Wilkins Co., Baltimore.

5. Grant, W. D., and H. Larsen. 1989. Extremely halophilic archaeobacteria, order Halobacteriales ord. nov., p. 2216-2233. In J. T. Staley, M. P. Bryant, N. Pfennig, and J. G. Holt (ed.), Bergey's manual of systematic bacteriology, vol. 3. The Williams and Wilkins Co., Baltimore.

6. Jackman, P. J. H. 1987. Microbial systematics based on electrophoretic whole-cell protein patterns. Methods Microbiol. 19:209225.

7. Jukes, T. H., and C. R. Cantor. 1969. Evolution of protein molecules, p. 21-132. In H. N. Munro (ed.), Mammalian protein metabolism, vol. 3. Academic Press, New York.

8. Kamekura, M., D. Oesterhelt, R. Wallace, P. Anderson, and D. J. Kushner. 1988. Lysis of halobacteria in Bacto-Peptone by bile acids. Appl. Environ. Microbiol. 54:990-995.

9. Kostrikina, N. A., I. S. Zvyagintseva, and V. I. Duda. 1991. Cytological peculiarities of some extremely halophilic soil archaeobacteria. Arch. Microbiol. 156:344-349.

10. Kroppenstedt, R. M. 1982. Anwendung chromatographischer HPVerfahren (HPTLC und HPLC) in der Bakterien-Taxonomie. GIT Labor Med. 5:266-275.

11. Larsen, H. 1989. Genus IV. Halococcus, p. 2228-2230. In J. T. Staley, M. P. Bryant, N. Pfennig, and J. G. Holt (ed.), Bergey's manual of systematic bacteriology, vol. 3. The Williams and Wilkins Co., Baltimore.

12. Malik, K. A. 1983. A modified method for the cultivation of phototrophic bacteria under anaerobic conditions. J. Microbiol. Methods 1:343-352.

13. McGenity, T. J., and W. D. Grant. 1993. The haloalkaliphilic archaeon (archaebacterium) Natronococcus occultus represents a distinct lineage within the Halobacteriales, most closely related to the other haloalkaliphilic lineage (Natronobacterium). Syst. Appl. Microbiol. 16:239-243.

14. McGenity, T. J., I. S. Zvyagintseva, and W. D. Grant. Unpublished data.

15. Mesbah, M., U. Premachandran, and W. Whitman. 1989. Precise measurement of the $\mathrm{G}+\mathrm{C}$ content of deoxyribonucleic acid by high-performance liquid chromatography. Int. J. Syst. Bacteriol. 39:159-167.

16. Montero, C. G., A. Ventosa, F. Rodriguez-Valera, M. Kates, N. Moldoveanu, and F. Ruiz-Berraquero. 1989. Halococcus saccharolyticus sp. nov., a new species of extremely halophilic nonalkaliphilic cocci. Syst. Appl. Microbiol. 12:167-171.

17. Norton, C. F., and W. D. Grant. 1988. Survival of halobacteria within fluid inclusions in salt crystals. J. Gen. Microbiol. 134:13651373.

18. Norton, C. F., T. J. McGenity, and W. D. Grant. 1993. Archaeal halophiles (halobacteria) from two British salt mines. J. Gen. Microbiol. 139:1077-1081.

19. Reistad, R. 1970. On the composition and nature of the bulk protein of extremely halophilic bacteria. Arch. Mikrobiol. 71:353360.

20. Rodriguez-Valera, F. 1988. Characteristics and microbial ecology of hypersaline environments, p. 4-30. In F. Rodriguez-Valera (ed.), Halophilic bacteria, vol. 1. CRC Press, Boca Raton, Fla.

21. Ross, H. N. M., W. D. Grant, and J. E. Harris. 1985. Lipids in archaebacterial taxonomy, p. 289-299. In M. Goodfellow and D. E. Minnekin (ed.), Chemical methods in bacterial systematics. Academic Press, London.

22. Smibert, R. M., and N. R. Krieg. 1981 . General characterization, p. 409-443. In P. Gerhardt, R. G. E. Murray, R. N. Costilow, E. W. Nester, W. A. Wood, N. R. Krieg, and G. B. Phillips (ed.), Manual of methods for general microbiology. American Society for Microbiology, Washington, D.C.

23. Stan-Lotter, H., F. J. Lang, Jr., and L. I. Hochstein. 1989. Electrophoresis and isoelectric focusing of whole cell membrane proteins from the extremely halophilic archaebacteria. Appl. Theor. Electrophor. 1:147-153.

24. Stan-Lotter, H., M. Sulzner, E. Egelseer, C. F. Norton, and L. I. Hochstein. 1993. Comparison of membrane ATPases from extreme halophiles isolated from ancient salt deposits. Origins Life 23:53-64. 
25. Tindall, B. J. 1990. A comparative study of the lipid composition of Halobacterium saccharovorum from various sources. Syst. Appl. Microbiol. 13:128-130.

26. Tindall, B. J., A. A. Mills, and W. D. Grant. 1980. An alkaliphilic red halophilic bacterium with low magnesium requirement from a Kenyan soda lake. J. Gen. Microbiol. 116:257-260.

27. Tomlinson, G. A., and L. I. Hochstein. 1976. Halobacterium saccharovorum sp. nov., a carbohydrate-metabolizing, extremely halophilic bacterium. Can. J. Microbiol. 22:587-591.

28. Visuvanathan, S., V. S. Moss, J. L. Stanford, J. Hermon-Taylor, and J. J. McFadden. 1989. Simple enzymatic method for isolation of DNA from diverse bacteria. J. Microbiol. Methods 10:59-64.

29. Witte, A., G. Wanner, U. Bläsi, G. Halfmann, M. Szostak, and W. Lubitz. 1990. Endogenous transmembrane tunnel formation mediated by $\phi X 174$ lysis protein E. J. Bacteriol. 172:4109-4114.

30. Zharkov, M. A. 1981. History of paleozoic salt accumulation. Springer Verlag, Berlin.

31. Zvyagintseva, I. S., and A. L. Tarasov. 1987. Extreme halophilic bacteria from soils. Microbiology (Engl. Transl. Mikrobiologiya) 56:839-844. 